\title{
New County Record For The Veiled Chameleon, Chamaeleo calyptratus Duméril and Bibron 1851 (Sauria: Chamaeleonidae), in Florida
}

Christopher R. Gillette ${ }^{1}$ and Kenneth L. Krysko ${ }^{2}$

${ }^{1}$ Florida International University, Department of Environmental Studies, Modesto Maidique Campus, 11200 SW 8th Street, Miami, Florida 33199, USA (cgill002@fiu.edu) ${ }^{2}$ Florida Museum of Natural History, University of Florida, Gainesville, Florida 32611, USA (kenneyk@flmnh.ufl.edu)

Photograph by the senior author.

$\mathrm{T}$ he Veiled Chameleon (Chamaeleo calyptratus Duméril and Bibron 1851) is a diurnal and arboreal lizard species indigenous to the Asir Province in southwestern Saudi Arabia to Aden in Yemen, where it lives on high, dry plateaus at elevations to $2,800 \mathrm{~m}$ and in foothills, forests, low-elevation maize fields, and inland river valleys (Fritz and Schütte 1987, Meerman and Boomsma 1987, Zari 1993, Showler 1995,
Schmidt 2001). Chamaeleo calyptratus is common in the pet trade, and has been intentionally and illegally introduced to the United States in Hawaii (Kraus and Duvall 2004, Kraus 2009) and Florida (Krysko et al. 2004). In Florida, this species is known to have been independently introduced to at least four sites, including Alachua, Collier, Hendry, and Lee counties (Enge 2008; Krysko et al. 2004, 2011b). Herein, we

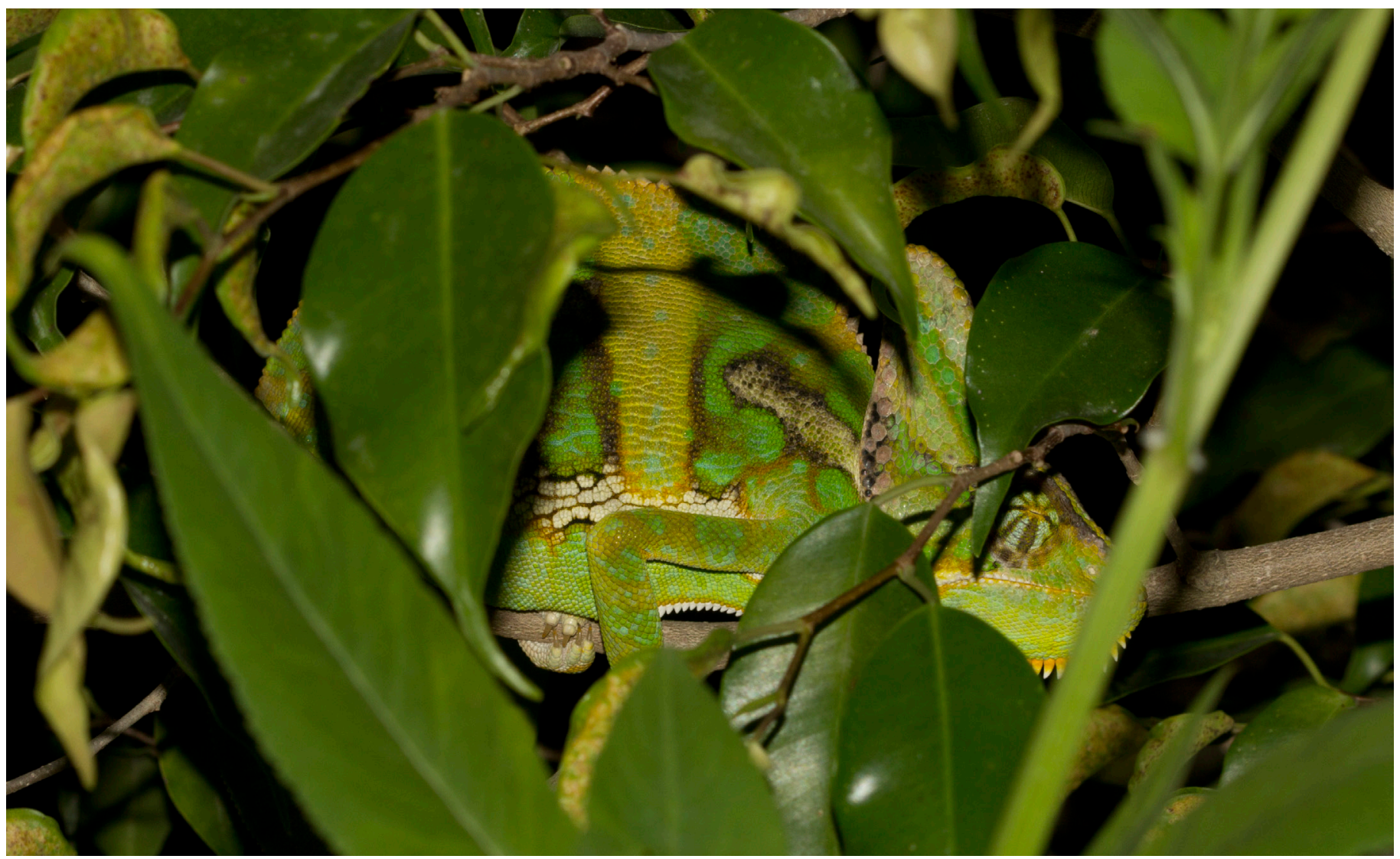

In situ photograph of adult Veiled Chameleon (Chamaeleo calyptratus) sleeping on a Weeping Fig (Ficus benjamina) in Homestead, Miami-Dade County, Florida, on 10 April 2012. 
document a new introduction of this species in Miami-Dade County, Florida.

On 10 April 2012 at 2145 h, CRG found an adult male Chamaeleo calyptratus (photographic voucher UF 166817). The identity of the lizard was confirmed by Max A. Nickerson, Christopher V. Anderson, and Robert H. Robins. The chameleon was sleeping in a hedge of Weeping Fig (Ficus benjamina) about $1.2 \mathrm{~m}$ above the ground on SW 212th Avenue, $0.06 \mathrm{~km}$ north of SW 352nd Street, Homestead, Miami-Dade County, Florida $\left(25.440825^{\circ} \mathrm{N}, 80.533807^{\circ} \mathrm{W}\right.$, Datum WGS84, 2 m elevation). This individual likely was released or had escaped from an enclosure at a nearby reptile facility because (1) this species does not have known established populations in areas leading to the site; (2) the closest known specimen locality is ca. $139 \mathrm{~km}$ northeast in Golden Gate, Collier County (photographic voucher UF 140472; Krysko et al. 2011b); and (3) the pet trade is the most common introduction pathway for introduced herpetofauna in Florida (Krysko et al. 2011a). Because applicable laws are difficult to enforce and both residents and legal authorities often are unconcerned, the ever-increasing trend of introduced herpetofauna in Florida continues.

\section{Acknowledgments}

Walter S. Judd, Marc S. Frank, and Kent D. Perkins confirmed the identity of the plant. Gad Perry, Robert Powell, and an anonymous reviewer provided helpful comments on this paper.

\section{Literature Cited}

Enge, K.M. 2008. Geographic distribution: Chamaeleo calyptratus (Veiled Chameleon). Herpetological Review 39:367.

Fritz, J.P. and F. Schütte. 1987. Zur Biologie jemenitischer Chamaeleo calyptratus Duméril \& Duméril, 1851 mit einigen Anmerkungen zum systematischen Status (Sauria: Chamaeleonidae). Salamandra 23:17-25.

Kraus F. 2009. Alien Reptiles and Amphibians: A Scientific Compendium and Analysis. Springer, New York.

Kraus, F. and F. Duvall. 2004. New records of alien reptiles and amphibians in Hawaii. Bishop Museum Occasional Papers (79):62-64.

Krysko, K.L., J.P. Burgess, M.R. Rochford, C.R. Gillette, D. Cueva, K.M. Enge, L.A. Somma, J.L. Stabile, D.C. Smith, J.A. Wasilewski, G.N. Kieckhefer III, M.C. Granatosky, and S.V. Nielsen. 2011a. Verified non-indigenous amphibians and reptiles in Florida from 1863 through 2010: Outlining the invasion process and identifying invasion pathways and stages. Zootaxa (3028):1-64.

Krysko, K.L., K.M. Enge, and F.W. King. 2004. The Veiled Chameleon, Chamaeleo calyptratus: A new exotic species in Florida. Florida Scientist 67:249-253.

Krysko, K.L., K.M. Enge, and P.E. Moler. 2011b. Atlas of Amphibians and Reptiles in Florida. Final Report, Project Agreement 08013, Florida Fish and Wildlife Conservation Commission, Tallahassee.

Meerman, J. and T. Boomsma. 1987. Beobachtungen an Chamaeleo calyptratus calyptratus Duméril \& Duméril, 1851 in der Arabischen Republik Jemen (Sauria: Chamaeleonidae). Salamandra 23:10-16.

Schmidt, W. 2001. Chamaeleo calyptratus, the Yemen Chameleon. Matthias Schmidt Publications Natur und Tier-Verlag, Berlin.

Showler, D. 1995. Reptile observations in Yemen, March-May 1993. British Herpetological Society Bulletin (53):13-23.

Zari, T.A. 1993. Effects of body mass and temperature on standard metabolic rate of the Desert Chameleon Chamaeleo calyptratus. Journal of Arid Environments 24:75-80. 